\title{
New methods of microbiological identification using MALDI-TOF
}

\author{
Novas metodologias de identificação de micro-organismos: MALDI-TOF
}

\author{
Jacyr Pasternak*
}

\begin{abstract}
Rapid diagnosis of pathogens is decisive to guarantee adequate therapy in infections: culture methods are precise and sensitive, but rather slow. New resources are available to enable faster diagnosis, and the most promising is MALDI-TOF technology: mass spectrometry applied to microbiological diagnosis. Times as fast as 10 to 15 minutes to etiological diagnosis are possible after a positive blood culture result. We hope to have this technology in our laboratory, ANVISA permitting and improving their very slow rate of doing things... MALDI-TOF is basically putting a sample of culture or an enriched suspension of the probable pathogen over a small spot with a matrix and vaporizing it with a laser pulse: the products are aspired into a chamber, ionized and reach detectors at variable times: the detectors show time of arrival and quantity of the product, and each pathogen has its characteristic spectrum analyzed by a software.
\end{abstract}

Keywords: Spectrometry, mass, matrix-assisted laser desorptionionization/methods

\section{RESUMO}

0 diagnóstico rápido de patógenos é crucial para a terapêutica adequada. 0 método clássico de cultura é preciso e sensível, mas demorado; novos métodos permitem um diagnóstico muito mais rápido, que pode ser tão precoce como 15 minutos após obter um material enriquecido. Em uma hemocultura, por exemplo, é possível saber 0 agente etiológico nesse prazo, assim que a cultura se mostrar positiva. Esse novo método é o MALDI-TOF, uma aplicação da espectrometria de massa à microbiologia: 0 material é colocado em uma placa com matriz e bombardeado com um laser que 0 evapora; um sistema ioniza e aspira 0 material volatilizado, que chega a detectores, os quais registram o tempo em que a substância chega ao detector e sua quantidade. Cada patógeno tem um espectro característico que é analisado por um software.

Descritores: Espectrometria de massa por desorção-ionização de laser em matriz/métodos
The microbiological identification of pathogen fungii and bacteria has been classically performed using methods that involve culture and, later, phenotypic tests exploring the metabolic differences among several species.

Cultures are extremely powerful methods to retrieve pathogens: theoretically a single viable pathogen in an appropriate medium multiplies in logarithmic scale, thus amplifying the signal from samples with very few agents. However, cultures take time depending on the pathogen, and they can be positive as early as within four to six hours or as late as some weeks, and the phenotypic tests could delay over 24 or 48 hours. In some circumstances, such as bacteremia, the appropriate identification and treatment (and it is understandable that one results from the other) are critical: some classic works, such as by Kumar et al., clearly show that for each hour delaying the adequate management of sepsis, mortality rises by 10 to $20 \%{ }^{(1)}$. Length of hospital stay and the price of admission equally decrease with early identification of the etiology of sepsis ${ }^{(2)}$.

New diagnostic methods have been developed, and they do not depend on bacterial or fungal growth and are effective even when the pathogens are not viable. The methods employing nucleic acids are already in clinical use; however, although faster than cultures, they demand technical time and at least 6 to 8 hours of work by a dedicated professional. A major advance is the use of proteomic studies for rapid diagnosis - as fast as 5 to 15 minutes - of etiology of infections, and it is represented by MALDI-TOF.

MALDI-TOF stands for Matrix Associated Laser Desorption-Ionization - Time of Flight and consists of a system in which biological material (a colony or

* Infection Control Committee, Hospital Israelita Albert Einstein - HIAE, São Paulo (SP), Brazil.

Corresponding author: Jacyr Pasternak - Avenida Albert Einstein, 627, consultório 1.316, $13^{\circ}$ andar - Morumbi - Zip code: $05651-901$ - São Paulo (SP), Brazil - Phone.: (11) 3747-2430 and 3062-0535 E-mail: jpaster@einstein.br

Received on: Jan 5, 2012 - Accepted on: Feb 5, 2012

Conflict of interest: None 
a blood culture concentrate) is placed on a plate that has a polymeric matrix. This is irradiated with a laser that vaporizes the sample with ionization of several molecules, which are aspirated in a vacuum tube and taken to a detector: the time of flight varies according to the molecule. This is transferred to a chart with several peaks and each bacterial or fungal species has a specific graph. A computerized database interpreters and provides the result - all very fast ${ }^{(3)}$. Therefore, it is a mass spectrometry application.

This technique enables making complex microbiological diagnoses, such as the correct specification of coagulasenegative staphylococci ${ }^{(4)}$ or the sorologically slow and subject-to-error definition of Salmonella enterica serovars ${ }^{(5)}$. It is possible to diagnose medically important fungii ${ }^{(6)}$, as well as mycobacteria with some technical modifications ${ }^{(7)}$. As the technique is more often used, the databases become more complete and identification improves. The databases are proprietary, which is a disadvantage when compared to nucleic acid databases, such as BLAST, which are public and for free, but subject to wrong deposits and alterations. And the proteomic databases, are so far more carefully evaluated before being updated. By the way, updating is a permanent process and is included in the contract to use the machines.

The devices are already available for demonstration in Brazil and we hope the Agência Nacional of Vigilância Sanitária (Anvisa) [National Health Surveillance Agency] will not hold registry, so that we can have this powerful resource to benefit our patients. Microbiology has always been very slow in the clinical laboratory as compared to other areas. Finally, we can provide the results in a useful and timely manner. There is no point in explaining to clinicians which is our bacterium carefully cultivated after the patient has passed away.

The antibiogram is stays as a typically phenotypic test, which requires an isolated, viable bacterium in a pure culture. This test will take some time but there is evidence that proteomic studies could at least suggest some types of resistances.

\section{REFERENCES}

1. Kumar A, Roberts D, Wood KE, Light B, Parrillo JE, Sharma S, et al. Duration of hypotension before initiation of effective antimicrobial therapy is the critical determinant of survival in human septic shock. Crit Care Med. 2006; 34(6):1589-96

2. Beekmann SE, Diekema DJ, Chapin KC, Doern GV. Effects of rapid detection of bloodstream infections on length of hospitalization and hospital charges. J Clin Microbiol. 2003;41(7):3119-25.

3. Benagli C, Rossi V, Dolina M, Tonolla M, Petrini O. Matrix-assisted laser desorption ionization-time of flight mass spectrometry for the identification of clinically relevant bacteria. PLoS One. 2011;6(1):e16424.

4. Carpaij N, Willems RJ, Bonten MJ, Fluit AC. Comparison of the identification of coagulase-negative staphylococci by matrix-assisted laser desorption ionization time-of-flight mass spectrometry and tuf sequencing. Eur $\mathrm{J}$ Clin Microbiol Infect Dis. 2011;30(10):1169-72.

5. Dieckmann R, Malorny B. Rapid screening of epidemiologically important Salmonella enterica subsp. enterica serovars by whole-cell matrix-assisted laser desorption ionization-time of flight mass spectrometry. Appl Environ Microbiol. 2011;77(12):4136-46.

6. Cassagne $C$, Ranque $S$, Normand AC, Fourquet P, Thiebault S, Planard C, et al. Mould routine identification in the clinical laboratory by matrix-assisted laser desorption ionization time-of-flight mass spectrometry. PLoS One. 2011; 6(12):e28425.

7. El Khéchine A, Couderc C, Flaudrops C, Raoult D, Drancourt M. Matrix-assisted laser desorption/ionization time-of-flight mass spectrometry identification of mycobacteria in routine clinical practice. PLoS One. 2011;6(9):e24720. 